\title{
CHARACTERPATHY, THE POSITION OF THE INDIVIDUAL IN THE FIELD OF JOUISSANCE AND THE STRUGGLE TO BUILD AN ANALYZABLE SYMPTOM*
}

Paula Duarte Félix Marinho and Márcia Maria Rosa Vieira Luchina

Paula Duarte Félix

Marinho

Universidade

Federal de Minas

Gerais (UFMG),

Departamento

de Psicologia,

Programa de

Graduação, Belo

Horizonte/MG,

Brasil

Márcia Maria Rosa

Vieira Luchina

Universidade

Federal de Minas

Gerais (UFMG),

Departamento

de Psicologia,

Programa de

Graduação, Belo

Horizonte/MG,

Brasil

\begin{abstract}
As we introduce the concept of character, formulated by some theorists of psychoanalysis, we are able to spot an important theoretical and clinical device to investigate the manifestations of psychic distress. The character presumes something more archaic than the symptom; therefore it emerges before its formation. The pathologies of the character, also called characteropathies, are subjective presentation forms in which the outputs of the subject through the act to the detriment of the word and the meaning predominate. They bring challenges in the installation of the symptom as analyzable, due to the jouissance of difficult symptomatization presented by the subject. Bearing this in mind, we will also approach some contributions concerning the direction of the treatment in such cases.
\end{abstract}

Keywords: Character, characteropathies, symptom, jouissance.

RESUMO: Caracteropatia, a posição do sujeito no campo do gozo e as dificuldades na instalação do sintoma como analisável. Ao resgatarmos a noção de caráter em alguns teóricos da psicanálise, localizamos nele um operador teórico-clínico importante para a investigação de manifestações de sofrimento psíquico. O caráter supõe algo mais arcaico do que o sintoma, portanto, anterior ao estágio de formação do sintoma. As caracteropatias, ou patologias do caráter, são formas de apresentação subjetiva nas quais predominam as saídas do sujeito pela via do ato em detrimento da palavra e do sentido. Elas trazem desafios na instalação do sintoma como analisável, devido ao modo de gozo de difícil sintomatização apresentado pelo sujeito. Com isso em vista, abordaremos também algumas contribuições quanto à direção do tratamento nesses casos.

Palavras-chave: Caráter, Caracteropatias, sintoma, modo de gozo.

DOI - http://dx.doi.org/10.1590/S1516-14982016002002

\footnotetext{
* This text was originally a chapter of the Master's dissertation entitled "Morbid obesity: from the crazed character of the drive to the analyzable symptom" presented at the Graduation Program in Psychology, Psychoanalytical Studies (UFMG) in 2012, under the supervision of Professor Márcia Maria Rosa Vieira Luchina.
} 
$\mathrm{I}^{\mathrm{n}}$ the following text we will present a brief resumption of different readings concerning characteropathies presented for analysis. Therefore, we will discuss the notion of character in what it presents to a disconnected drive satisfaction of a question that would puzzle the subject, that is, as something distinct from the symptom.

Character is a term included in the work of Freud, but in a much dispersed way. Therefore, we cannot say that there is an actual theory of the character in Freud's work, different from what we see in the drive or the symptom. However, he gives, in some of his texts, reasonable importance to that notion, which probably served as a stimulus to some of his followers like Karl Abraham and Wilhelm Reich.

\section{THE NOTION OF CHARACTER IN FREUD, ABRAHAM AND REICH}

In the Three essays on the theory of sexuality from 1905, Freud states that: "What we describe as how the ' character ' of a person is built, in large part, with the material of sexual excitement and consists of impulses that have been fixed since childhood (...)" (FREUD, 1905a/1974, p. 246). Another important point is the fact that the psychic solution of the construction of the character is seen as an alternative to neurosis - that would be installed if these excitations were fully contained by the mechanism of repression and find solution through the symptom.

In "the psychoanalytic method" (1905) Freud proposes that the character comes across as a source of strength: "(...) distortion of the character that are deeply rooted, traits of a truly degenerate constitution, are sources of resistance during the treatment that can hardly be surpassed" (FREUD, 1905b/1972, p. 262).

In "Some Character-Types Met with in Psycho-Analytic Work" (1916), Freud describes, from clinical fragments and literary examples, cases where he locates acts and behaviors that would be exceptions to the constitution of the neurotic symptoms in general and therefore represent difficulties in analytical work. It is important to remember that this article is contemporary to his Introductory Conferences (1916-1917), where several topics about the neurotic symptoms and its aspects are developed. We can see that to Freud, character and symptom are not the same thing.

In the above mentioned article, Freud submits some comments on the technical difficulties that some types of character tend to present in the clinic and associates them to the resistance. At the beginning of the first part of the text he states: 
(...) When a doctor takes the psychoanalytic treatment of a neurotic person, his interest is not driven at first to the character of the patient. He would rather know what the symptoms mean (...).However, the technique he is obliged to follow soon compels him to drive his immediate curiosity to other objectives. He notes that his investigation is threatened by resistances raised against him by the patient, so the doctor, with good reason, faces these resistances as part of the character of the patient. This, then, acquires the priority of his interest (FREUD, 1916/1974, p. 351).

In the part entitled "The exceptions", the author states that the analytical work continually requires the patient to renounce an immediate and directly attainable dose of pleasure, in order to make him give up satisfactions that will bring harmful consequences, thus learning to change an immediate dose of pleasure for a safer, albeit delayed one (FREUD, 1916/1974). Freud warns that there are individuals who resist this relinquishment of satisfaction for a particular reason. They think they're right to be spared of any requirement, because they have suffered a lot in their lives and have renounced many things, putting themselves in the place of exceptions whose opposing arguments have no effect on such conviction, and the therapist has only to find out the sources through which this harmful preventing is being fed. (FREUD, 1916/1974).

One of the common causes of exception was caught by Freud in the earliest experiences of the lives of these patients, whose neuroses were linked to some experience of suffering or to some congenital handicap which were submitted in childhood and which had no guilt, an experience which was seen as an injustice imposed by others, justifying, therefore, for these patients, the right to do whatever they wanted.

In this type of character, we see the ferocity of the drive and its satisfaction, in that the guy can't defend himself from the drive imperative past, where, under the massive effect of the drive, it passes to the Act, no the refusal, he cannot be deprived. The exception- type character described by Freud is the one in which the subject does not waive enjoyment, or its attachment on it.

In the Ego and the Id (1923), Freud provides a few more details about the formation of the character, when he says that the character derives from the self-constitution, the way it is shaped from the abandonment or loss of a sexual object when it absorbs the characteristics of this object. The character consists of a resulting set of these modifications of the self, featuring a precipitate of abandoned objective-cathexis that attract drive investments, and, also resist the return of these, becoming more clearly fixed, making 
evident that the effects of the first identifications in childhood are general and long-lasting. (FREUD, 1923/1974).

The German psychiatrist and psychoanalyst Karl Abraham (1877-1925), a disciple of Freud, presented its most important and significant contributions to psychoanalysis through the work Psychoanalytic Theory of the Libido, 1924. In this book, his main work, there are three papers dealing, in particular, with the oral, anal and genital of the character. His most significant contribution seems to be the one that refers to the oral eroticism.

In his research, Abraham (1924/1970) also approached the influence of oral eroticism on character formation. According to him, elements of the infantile sexuality, which are excluded from the participation in the sex life of the adult, partly turn into character traits.

According to Freud (1974), in childhood, the individual has an intense pleasure in the act of sucking, and that this should not be entirely connected to the process of food intake, but that it is, in high degree, related to the meaning of the mouth as an erogenous zone. This early form of obtaining pleasure, according to Abraham, is never completely abandoned by the individual, but remains disguised and even experiences intensification in some special circumstances. Thus, Abraham States that, in certain cases, the whole character of the person is under the oral influence, after a thorough analysis and that, in such cases, the suction was not disturbed but highly satisfactory.

We are particularly interested in an observation made by the author in the above mentioned book because it demonstrates the strength of the action of the drive. He warns that in addition to the characterologic oral traits described, there are people where the impulses of oral origin escaped all social modification: "As an example of those, it should be mentioned, especially, a morbid appetite, intense, for food and an inclination to various oral perversions" (ABRAHAM, 1924/1970, p. 171). He claims that certain features of this neurotic hunger should be noted as having no relationship with having or not an empty stomach, so it is not associated with the normal need of nutrition and is accompanied by feelings of anxiety. In the complaints of these patients the "devouring hunger crisis" are very clear. They even recognize the difference between normal hunger and this "devouring hunger", but they tend to be more inclined to confuse the two conditions (ABRAHAM, 1924/1970).

As an explanation, Abraham states that strong libidinal impulses may be disguised by a sensation of hunger: "In some cases, the impulse can be so strong that the patient is forced to adapt and subordinate his whole way of life to his morbid desire for food" (ABRAHAM, 19241/1970, p. 65). Further, he states that the behavior of these patients, who crave for food in short intervals of time and undergo tortures if their wishes are not satisfied, resembles those 
addicted to morphine, and a great number of dipsomaniacs. In this case we can observe the strength of the drive which is not regulated by repression, leading the subject to compulsive acts.

One of the other followers of Freud, Wilhelm Reich (1897-1957), an Austrian psychiatrist and psychoanalyst, produced in the period between 1920 and the early 1930s, some of his most important works about the notion of the character. It was at this time that the author, then engaged in the psychoanalytic movement, developed his concept of character and organized his first therapeutic technique, the analysis of the character.

In 1922, Reich wrote the work entitled "Two narcissistic types", in which he makes his first references to the term character. He claims there is a distinction between neurosis and character in relation to its mechanism of formation and method of presentation. In neurosis, the symptoms would be located and defined, and in the character neuroses, the symptoms would be more diffuse, without a clear location and mingled with the entire way of being of the patient.

To understand this difference, he elaborates his own thesis. For him, the explanation of the difference between neurosis and character neuroses would be in relation to the type of libidinal investment in relation to the target of this investment. That is, if the drive that takes an external object as a target is more strongly disturbed by the process of repression, there is the possibility of developing a neurosis with a clear delineation of the symptoms, in a close symbolic relationship with the repressed desire and the drives at stake. However, if the drives take the self as the object, they are the ones that are more disturbed, the symptoms are diffuse and extensive, impossible to be separated from the personality set.

Then, Reich presents some typical characteristics of the clinic with patients showing character neuroses, contrasting with neurotic patients (symptomatic). According to him, in patients affected by character neuroses, there's a greater delay and less intensity in the establishment of a positive transfer, which results in a difficult treatment, because the therapy would mean a threatening dimension to them. As a result of this process, defenses or narcissistic "armors" always come up and the therapist must skillfully know how to deal.

In his book of 1925, The Impulsive Character: a Psychoanalytic Study of Ego Pathology, Reich outlines more clearly what he means by character. He also gives emphasis to the impulsive character that would be a specific form of neurotic character dominated by the drive. According to the author, this form of character occurs when the drive inhibition occurred so faulty, resulting in 
the non-integration between the self and the superego in the psyche as a whole, leaving the latter in isolation.

Another interesting observation of Reich relates to the fact that, for the author, the character analysis must first promote the analysis of actions and behaviors, rather than a "memory analysis" (REICH, 1925/1975), that is, an analysis focused on the memories of the patient. The actions would have privileged expression about the memories in character, that is, there's a bond between character and action, which creates difficulties with regard to the analytical interpretation: "(...) the actions are little adapted to the analyticalgenetic interpretation without subsequent memories or without at least an analytical reconstruction of the sources of behavior "( $\mathrm{REICH}, 1925 / 1975$, p. 239).

We have noticed that Reich was willing to search for new ways of clinical intervention, ways which would be able to cope with this dimension in the therapy, distinct from the symptom.

In Character Analysis, published in 1933, Reich justifies that his book is the result of therapeutic issues found in the psychoanalytic research that he carried out at the Vienna Psychoanalytical Clinic. As he states, in this work he held a description and a detailed explanation of the principles of the technique that originated the character analysis (REICH, 1933/979).

Reich says that few patients are able to follow the analytical rule right from the start, for a variety of reasons, as described by him: the patient's difficulty in trusting the therapist, the period of the disease, the lasting influence of a neurotic environment, bad experiences with neurology doctors. In summary, due to a whole secondary fragmentation of the self, it would result in a situation which is averse to therapy. Soon, the elimination of this difficulty becomes a prerequisite for the therapy. However, this becomes more difficult due to the character of the patient, which is a part of the neurosis, being known by the name of "narcissistic barrier". Later, in the fourth chapter of the first part of the book, entitled "On the technique of character analysis", the author states:

(...) there are neurosis with circumscribed symptoms and neuroses without symptoms: the former would be called "symptom neuroses" and the later "character neuroses". In the former, understandably, the symptoms are more evident, the character traits are evident (...) the symptom neuroses is recognized as being always based on a neurotic character, so, it's obvious that in each therapy we have to count on resistances that are manifestations of a neurotic character (REICH,1933/ 1979, p.74). 
Reich says, still with regard to the distinction between symptomatic neurosis and character neurosis, that a lack of knowledge of the disease by the patient is certainly an essential indication of the character neurosis.

The second important practical difference, according to the author, is related to the fact that neurotic symptoms never show complete and authentic rationalizations that appear to be meaningless. In the case of the neurotic character, he is rationally motivated to not look like pathological or absurd. In addition, according to Reich, the patients with traits of neurotic character try to justify their condition, saying that they were "born" like this. However, the character is analyzable and changeable, as well as the symptom. Another important point is the fact that the symptom has a simple structure if compared to the trace of character, since it is determined by a limited number of unconscious attitudes. The character, however, is based on a multiplicity of antagonistic efforts and expresses an attitude or mode of existence: "The attitude does not dissect as easily as the symptom, (...) but either one or the other can return to the origin and be understood based on impulses and experiences" (REICH, 19331/1979, p. 77).

The author still presents the idea that the symptom could not arise if there wasn't already a foundation for a neurotic reaction in the character. Reich defines as "armor" of the character a defense mechanism which is chronically located in the psychic structure, and is observable in the way the patient is presented in the therapy.

The function of this defensive armor is to essentially move away the anguish, since therapy constitutes a danger to this balance, albeit neurotic: "(...) it's about this narcissistic defense mechanism of the self that the resistances originate and which give the individual case therapy its special characteristics (REICH, 1933/1979, p. 77).

In relation to the analysis of symptoms, the author states that, in the case of character analysis, the therapist should:

(...) show the patient the trait of isolated character, and this, over and over, until he can free himself and regard it as an obtrusive compulsive symptom. To break free and to objectify the neurotic character trait, the patient begins to feel it as something that is strange to him and, finally, gets knowledge of the disease (REICH, 1933/1979, p. 83).

We can see then, through this brief journey of the bibliography of Freud, Reich and Abraham on the notion of the character, that this notion is essentially associated to the drive operation and to the resistance. 
Diana Rabinovich, in her book The Clinic of the Drive - the impulses (1989/2004), was one of the pioneers in the psychoanalysis of Lacanian orientation to discuss theoretically and clinically about psychopathologies manifestations resistant to the sense, manifestations that showed the drive profligacy by the massive and deadly use of the body, rather than a complaint or a minimally articulated symptom.

Two "classic" clinical descriptions are worked in this articulation: the characteropathies and the impulses. Some appear to be asymptomatic; others, such as bulimia, are easy to define based on an external standard, for example obesity, thereby eliminating the subjective demand at stake. According to the author, both indicate the presence of a certain drive satisfaction that blocks and slows down the clinical work with those that are presented like this. (RABINOVICH, 1989/2004).

The author also states that this characteropathic position can be read as a "pathology of the act". The characteropathic patient in question is not related to the symptom of being 'egosynchronic' or assimilated to the self, or being 'egodistonic'. The term in English, character, as well as designating the character, also designates a character. The characters and the character as a character, are closer to some installation in the egoic position:

"The position I call characteropathic is therefore something that corresponds more to a certain way of assuming the self (...) there's a specific disjunction that makes some patients come to an appointment from a position, which is not that of the symptom that makes questions, but that of a character, that of a "way of being", that does not make questions". (RABINOVICH, 19892/2004, p. 53).

These forms of psychic distress would not be, inside themselves, clinical structures. It is, according to her, the pathology of the identification with object $a$, where this is not latent, but practically in front of us. The subject would be settled in the place not of the question, but that of the answer, a place that houses an auto-erotic jouissance which also ensures the consistency of the Other. The passage to the act as an example of the pathology of the act is made explicit as an impulse related to the functioning of the drive. There is something related to the order of satisfaction that, when carried out directly, leaves the subject without a place.

To the author, these would be presentations of the subject on the side of the drive and not of the desire. Thus, we are talking about a subject who can't tell us almost anything but can show us this satisfaction (RABINOVICH, 1989/2004, p. 60). Therefore, these psychic phenomena cannot be placed on the side of the symptom, since they feature acts where the subject bets 
without the Other, where there wouldn't be an addressing, an appeal. The discontent that is produced relates to the fact that these subjects fail to delineate the drive effects of the formations of the unconscious.

\section{MILLER'S READING}

Jacques-Alain Miller, in his seventeenth Course of Lacanian Orientation, entitled La experiência de lo real en la cura psicoanalítica (1998-1999), finds the importance of resuming the contributions of some psychoanalysts throughout the history of psychoanalysis. He notes that the term resistance can be understood as an index that points to the real at stake in the analytical experience (MILLER, 1998/2011 p. 55), as well as the terms defense and negative transfer.

Lacan named as inertia what therapists had qualified as resistance and assigned to the imaginary everything that says ' $\mathrm{no}$ ' to therapeutic intervention. For Miller, then, it is a way to find, in the history of psychoanalysis, what we can mention as a "theory of the obstacle" to free association, to the symbolic operation; obstacles named until then as resistance or inertia.

With this intention, Miller specifically discusses the contribution left by Wilhelm Reich. The origin of the resumption of the Freudian term 'character' at that time, was related to the perception, by the psychoanalysts, of the inertia or resistance to free association.

Reich worked primarily on the approach of what resists to association, which is for him, the main focus of the treatment in its initial phase. He believed that only a minority of the patients was able to work in free association from the beginning of the therapy, since most of them couldn't submit to the analytical rule before the weakening of the defenses. (MILLER, 1998/2011, p. 65-66).

When you follow the work of Reich, one realizes that the notion of character is distinct from that of the symptom. What makes the character not a symptom lies in the fact that the symptom is never completely rationalized, because it has a parasitic operation with respect to the intention that, consequently, disturbs. The character is a kind of symptom integrated with personality and, therefore, difficult to approach. It is an economic manifestation that arises due to drive pressures, characterized as a armor, an obstacle in psyche not against the 'will to say', embodied by the vector of the question, but rather a armor formed as an answer of the 'will to jouissance' of the drive.

For Miller, Reich's approach is valuable when he supports that, in some cases, what we find in the therapy operation in the first place, is the obstacle of the character, whose paradoxical formation does not refer to an internal division of the subject being as seen on the symptom that causes suffering 
and strangeness. And the merit is related to the fact that, with his approach, he tried to undo this paradox, this ambiguity between the egosynchronic symptom and the egodistonic symptom.

This difference would be based on the fact that the character is something synchronic, integrated to the personality, as if there was a condensation of the symptoms, which would not cause discomfort, because it wouldn't be taken as something dysfunctional or disabling. Thus, the character shows a way to come integrated to the self, and a source of satisfaction of the drive. This synchronic manifestation is not represented by an internal division of the self of the subject, by a wish to be different, since it represents more of a subjective identity integrated with psyche.

According to Miller, Reich's method consists of undertaking in a first moment of the therapy, a subjective disidentification of the character, that is, its symptomization. The direction would be that of arousing the interest of the patient for some special feature or trait of his character and try to find its origin. Starting from this point, the therapy control would finally involve the perception of the character as something uncomfortable and painful, thus gradually catching up its status as a symptom. (MILLER, 1998/2011, p. 78-81).

\section{Symptom // Character}

According to his notion of character, Reich points out, not the statements of the subject, but their conduct and their actions, as if the character was something more archaic than the symptom, prior to the stage of its formation, where the drive fulfills in the action. It is presented as a pathology of conduct, expressed in the form of repetition, bordering on stereotypy, a pathology that illustrates the experience of the real, distinct from the division of the subject, from the unconscious and from the deciphering of its formations, which is close to, in phenomenological and Lacanian terms, the form of jouissance. (MILLER, 1998/2011, p. 79)

Befriedigung, the satisfaction, comes first in the character, to the detriment of Bedeutung, the meaning. In other words, the concept of character was the conceptual tool to extend neurosis far beyond the symptom. It's like there is, in this case, a direct connection, a short circuit between the character trait and a body function, between the character and the functioning of an organ. There is, therefore, the idea of the drive basis of the character (MILLER, 1999/2011).

According to Miller, the notion of character was the way found by the therapists of the twenties to theorize what was being presented as the incidence of the body in the unconscious, or, at least, the articulation of the 
unconscious with the body. The notion of character, much more than the symptom, provided its own device to think about the impact of the drive satisfaction rooted in the body on the subject. (MILLER, 1999/2011).

With respect to the subjects who present themselves in the 'characteropathic' form, if we rethink the notion of the armor in Reich, we can observe that, to Reich, the 'armor' represents a psychic narcissistic protective barrier, an effort to self-sufficiency, a defense. For Lacan, the imaginary obstructs the therapy, he names it as an imaginary armor, an obstacle that is not necessarily opposed to the outside world or to the drives, to the extent that his definition of the imaginary includes the outside world and the drive functioning, but what experiences as an imaginary obstacle embodied in this armor refers to an intention of symbolic order. (MILLER, 1998/2011). In other words, there would be a separation between the 'will to jouissance' and the 'will to say'.

Reich's notion of the character is related, according to Miller (1998/2011), with the Lacanian ghost, since it represents an individual's way of being specific, making the overall concept to approach the matrix of the whole meaning for a subject, the matrix that Lacan insulated as the ghost. We can observe the homology between the self and the ghost in the form of representing the way of being of a specific of a subject, thus making the notion of character approach, just like the ghost, the matrix of all the meaning for a subject.

To resume the notion of trait, particularly the character trait, it is necessary to mark the difference made by Lacan between the unary ${ }^{1}$ trait and a signifier trait which refers to another signifier (S1-S2) and that, consequently, points to the sense and to the articulation of a chain of signifiers. The problematic of the character, as a psychic manifestation averse to the meaning and the interpretation, and the difficulty of some subjects in symptomizing these traits, lead us to question the functioning of the chain of signifiers and what precedes it in its most primary and fundamental aspects.

Jacques Alain Miller in his sixth Course of Lacanian Orientation, entitled Los signos del goce (1986-1987), examines the developments of Lacan's last teachings in relation to the unary trait, signifier trait and to the insignia or sign of jouissance.

Miller says, in the part entitled "La sustracción del sujeto", particularly in the item named "Unary-binary", that there are some words that can apparently appear as the most trivial a subject may distinguish and takes them as his. These words deserve to be referred to as the first, that is, distinct, apart from the second. Lacan exemplifies them as the trait that is translated as unary ${ }^{2}$.

\footnotetext{
${ }^{1}$ Miller reports that unary is a neologism, which is used quite often both in logical language as in mathematics, where the term binary is also used, a term that was formed in the same way (MILLER, 1986/2006, p. 35).
} 
The binary is, for example, S1-S2. The unary, in turn, adjectivizes S1, when it is separated from $\mathrm{S} 2$ in the period that something was said and yet not repeated. With the ideal of the self, I (A), the signifier that would represent the subject is appointed, as long as it is out of the series.

Miller identifies this problematic from the theme of the insignia. In Escritos, Lacan defines insignia as an imaginary signifier, i.e., it is an image used as a signifier, and adds that this imaginary signifier appears indeed in the place of the signification (MILLER, 1987/2006). By the way, Miller points to a conceptual opposition made by Lacan, but not developed by him. It is the opposition between "chain" and "constellation".

According to the author, Lacan uses the term constellation because of the insignias, stating in his Escritos, more precisely in the text "Remarks on Daniel Lagache's Presentation" (1960): “(...) it is the constellation of insignia that make up the symbolic ego-ideal (LACAN, 1998, p. 686). Thus, Lacan says constellation of insignia because it is not a signifier chain. Miller states that this issue becomes crucial when we find that Lacan defines the signifier by means of articulation, that is, when he defines the subject as the one who is represented by a signifier for other signifier. Lacan turns this axiom into not only the definition of the subject, but also of that of the signifier itself, which would be equivalent to defining the signifier for his ability to articulate or not.

With the term constellation, Lacan points out a way of grouping the distinct signifier from the chain, and this, according to Miller, brings important consequences for the practice of psychoanalysis. With the insignia, Lacan points out a primal identification that is not, however, a representation.

According to Miller (1986/2006), with the term "constellation insignia", Lacan suggests that these iconic signifiers introduce a way of identification other than the one that is the grouping of traits in the signifier chain. In the chain grouping, the order of representation prevails and the signifier represents the subject before another signifier (S1-S2). However, these distinguishing marks may also "(...) capture the identification there where it is not a representation, there where the subject is taken for only one. The idea of constellation insignia implies exactly this "(MILLER, 1986/2006, p. 149-150). So, with the insignia, the subject is taken by the One, by a substance, an entity.

The paradox of this unique insignia is that it is an extremely economical construction because it highlights the two identities of S1: the identity as an insignia by itself (at this point, the subject comes from this signifier) and its identity as an articulation (MILLER, 1987/2006).

In his course entitled Los signos del goce (1986-1987), Miller covered the developments of Lacan's last teaching in relation to the unary trait, signifier trait and the insignia or sign of jouissance, differentiating the insignia and 
its constellation from the signifier that articulates in a chain that promotes the association, typical of the unconscious functioning.

The signifier chain would be in opposition to the constellation of insignia and this insignia defined as an imaginary signifier that would appear in the place of the signification. The insignia features a loose signifier, not articulated to the chain S1-S2, and that, for this reason, could not represent the subject as a signifier in relation to another signifier. With the insignia, the subject would be taken by a substance, an entity, being outside the symbolic system on its representative and communicative face, excluded from the effects of the sense, emerging as letter of jouissance.

\section{TREATMENT DIRECTIONS}

Next we will bring some contributions from authors who have thought over the theme in order to build treatment directions for the cases presenting difficulties in the analytical work due to the symbolic precariousness that results in the difficulty of bringing a complaint or an argument that can be symptomized.

Miller, in his seventeenth Lacanian Orientation Course, entitled La experiência de lo real en la cura psicoanalítica (1998-1999), regarding the direction of the treatment, proposes the interpretation as "disruption" so we can take care of some frequent manifestations at the contemporaneous clinic. The strategy of the intervention as "disruption" is interesting because it introduces something that goes beyond the unconscious; this disturbance is intended to remove the effect of the jouissance sense of the body, and, for such, acts by the bias of surprise, with the purpose of mobilizing something of that body and of splitting up the subject (MILLER, 19982003). It is meant to disturb the defense when the subject is presented by making with the body instead of saying.

The interpretation as a disturbance has the parletre as a destination, where the role of the unconscious is completed with the body. This mode of interpretation requires an analyst's contribution, as the look, the voice, intonation, gestures and pantomime. The interpretation as a disturbance approaches the body and the figure by the bias of the surprise, offering the subject a way out.

One of the possible ways of intervention in this regard is the construction, made possible by the therapist, of a symptom that makes a link or a connection to the unconscious. Mauricio Tarrab, in his text "Producing new Symptoms" (20052006), explains that this would be an attempt that a rambling jouissance is connected with some sense, that could produce access to the unconscious.

That way, one aims that this lonely and dull jouissance is encrypted in the unconscious and can later be deciphered. Thus, the jouissance would 
articulate to the sense, not necessarily as a synonym of signification, but in terms of direction, vectorialization. The analytical stake would be that if one translates what is performed as jouissance in terms of knowledge. As a result, a new approach to this jouissance would be obtained, promoting a savoir-y-faire, to know-how to do it.

Diana Rabinovich (1989/2004) states that a long previous work is required in cases where the defense is predominant, before the patient can take the place of the subject under therapy. This place would be, par excellence, the place of the divided subject. In relation to this point, these subjects can be phenomenologically characterized as spherical, "hard" (RABINOVICH, 1989/2004, p. 39). This preparation for the therapist's work would be necessary, because a subject immersed in jouissance would not be able to address any issue to the therapist and, therefore, his own free association would be compromised.

The possibility that this "character" gets annoyed with him is the point at which he can ask for something through which he can emerge as a subject. Many times the inconsistency of the Other is not presented to the subject with this type of symptomatic formation, and what appears are complaints against the Other, which is not the same thing. So, the therapist could, through these complaints, make way for a questioning of this Other in an excessive

consistency. This can cause the gain of jouissance from this position of oral object, for example, from this position to respond immediately to the demand of the Other, in which the subject is offered, and falters a little. (RABINOVICH, 1989/2004, p. 58).

By way of conclusion, we can diversify the opposition between character and symptom with respect to the attachment in jouissance. Because Freud himself was able to locate on the symptom an unconscious sense subject of decipherment, but also an irreducible satisfaction and unassimilable, the satisfaction of a language-irreducible jouissance, we assume that what is presented as a character trait in some subjects has, in Lacanian terms, the status of insignia, of letter of jouissance, of loose signifier, to the detriment of signifiers that form chains, contain senses and, in view of this, are more technologically savvy to interpretation. 
Recebido/Received: 21/2/2014. Aprovado/Accepted: 17/11/2014.

\section{REFERENCES}

ABRAHAM, K (1911-1924/1970) Teoria Psicanalítica da libido. Rio de Janeiro: Imago.

FREUD, S. (1905a/1974). Edição Standard Brasileira das Obras Psicológicas Completas. Rio de Janeiro: Imago. "Três ensaios sobre a teoria da sexualidade", v. VII, p. 135-175.

FREUD, S. (1905b/1972). Edição Standard Brasileira das Obras Psicológicas Completas. Rio de Janeiro: Imago. "O método psicanalítico de Freud”, v. VII, p. 254-262.

FREUD,S. (1916/1974). Edição Standard Brasileira das Obras Psicológicas Completas. Rio de Janeiro: Imago. "Alguns tipos de caráter encontrados no trabalho analítico", v. XIV, p. 351-377.

FREUD, S. (1920/1974). Edição Standard Brasileira das Obras Psicológicas Completas. Rio de Janeiro: Imago. "Além do princípio de prazer", v. XVII, p. 17-85.

FREUD, S. (1921/1976). Edição Standard Brasileira das Obras Psicológicas Completas. Rio de Janeiro: Imago. "Psicologia de grupo e análise do eu", v. XVIII, p. 91-131.

FREUD, S. (1923/1976). Edição Standard Brasileira das Obras psicológicas Completas. Rio de Janeiro: Imago. "O ego e o id”, v. XIX, p. 32-41.

LACAN, J. (1957/1998). “Observação sobre o relatório de Daniel Lagache: "Psicanálise e estrutura da personalidade", in Escritos. Rio de Janeiro: Jorge Zahar.

MILLER, J. A. (1986-1987/2006). A. Los signos del goce. Buenos Aires: Paidós.

MILLER, J. A. (1998-1999/2011). La experiência de lo real en la cura psicoanalítica. Buenos Aires: Paidós.

REICH, W. (1922/1975). "Two Narcissistic Types". In Early Writings, New York: Farrar, Straus and Giroux.

REICH, W. (1925/1975). "The Impulsive Character: a Psychoanalytic Study of Ego Pathology". In: Early Writings, New York: Farrar, Straus and Giroux.

REICH, W. (1933/1979). Análise do caráter. São Paulo: Martins Fontes.

RABINOVICH, D. Clínica da pulsão - as impulsões (1989/2004). Rio de Janeiro: Compahia de Freud: José Nazar

TARRAB, M. (2005/2006) Produzir novos sintomas. Revista Eletrônica do Núcleo Sephora v. 01 , n. 02. Rio de Janeiro: p. 01-14.

Paula Duarte Félix Marinho

paula.duarte.felix@terra.com.br

Márcia Maria Rosa Vieira Luchina

marcia.rosa@globo.com

Traduzido do português por Doris Dana/ translated from portuguese by Doris Dana

dorisdana@uol.com.br 
